\title{
Occult Adrenal Insufficiency in Renal Amyloidosis Patients
}

\author{
Renal Amiloidoz Hastalarında Gizli Adrenal Yetmezlik
}

\section{Didem TURGUT $\odot$, Serhan Vahit PISKINPASA $\odot$, Havva KESKIN $\odot$, Kemal AGBAHT $\odot$, Ezgi COSKUN YENIGUN $\odot$, Fatih DEDE $\odot$}

Ethics Committee Approval: This study was approved by the Ankara Numune Training and Research Hospital Ethics Committee, 7 September 2011, 2011-216.

Conflict of interest: The authors declare no conflicts of interest.

Funding: None.

Informed Consent: Informed consent was taken from the participants of the study.
Cite as: Turgut D, Piskinpasa SV, Keskin H, Agbaht K, Coskun Yenigun E, Dede F. Occult Adrenal Insufficiency in Renal Amyloidosis Patients. Medeni Med J. 2021;36:52-7.

\begin{abstract}
Objective: Systemic amyloidosis may affect many organs, and may cause endocrinologic problems which may result in adrenal insufficiency. However, assessment of adrenocortical reserve is challenging in amyloidosis patients with renal involvement. We aimed to evaluate adrenocortical reserve with various methods of cortisol measurement to determine any occult clinical condition.

Methods: Patients with renal amyloidosis and healthy subjects were evaluated in this crosssectional study. Basal cortisol, corticosteroid-binding globulin (CBG), and albumin levels were measured. Serum free cortisol (CFC) level was calculated. Cortisol response tests performed after ACTH stimulation test ( $250 \mu \mathrm{g}$, intravenously) were evaluated, and free cortisol index (FCI) was calculated.

Results: Twenty renal amyloidosis patients, and 25 healthy control subjects were included in the study. Patients and control subjects had similar median serum baseline cortisol levels [258 (126423) vs 350 (314-391) $\mathrm{nmol} / \mathrm{L}, p=0.169)]$ whereas patients' stimulated cortisol levels at the $60^{\text {h }}$ minute were lower [624 (497-685) vs $743(674-781) \mathrm{nmol} / \mathrm{L}, p=0.011)]$. The $60^{\text {h }}$-minute total cortisol levels of 8 of the $20(40 \%)$ amyloidosis patients were $<500 \mathrm{nmol} / \mathrm{L}$, but only three of these 8 patients had stimulated $F C I<12 \mathrm{nmol} / \mathrm{mg}$ suggesting an adrenal insufficiency (15\%). Conclusion: ACTH stimulation test and cortisol measurements should be considered in renal amyloidosis patients with severe proteinuria to avoid false positive results if only ACTH stimulation test is used. It will be appropriate to evaluate this group of patients together with estimated measurements as $\mathrm{FCl}$.
\end{abstract}

Keywords: Adrenocortical insufficiency, albumin, $C B G$, cortisol, renal amyloidosis

öz

Amaç: Sistemik amiloidoz birçok organı etkileyebilir ve adrenal yetmezlikle sonuçlanabilecek endokrinolojik problemlere sebep olabilir. Renal tutulumlu amiloidoz hastalarında ise adrenokortikal rezervi değerlendirmek zordur. Biz bu çalışmada farklı kortizol ölçüm yöntemleri ile renal tutulumlu amiloidoz hastalarında gizli adrenal problemlerini tespit etmeyi planladık.

Yöntem: Bu kesitsel çalışmada renal tutulumu olan amilodoz hastalarını ve sağlıklı kontrol grubunu adrenal yetmezlik testleri açısından değerlendirdik. Bazal kortizol ve kortizol bağlayıcı globulin (KBG) ölçüldü. Serum serbest kortizol düzeyi hesaplandı. $250 \mathrm{mcg}$ ACTH stimulasyon testi sonrası kortizol yanıt testleri değerlendirildi ve serbest kortizol indeksi (SKI) hesapland.

Bulgular: Çalışmaya 20 amilodoz hastası ve 25 sağlıklı kontrol grubu dahil edildi. Bazal serum kortizol düzeyleri hasta ve kontrol grubunda benzerdi [258 (126-423) vs 350 (314-391) nmol/L, $p=0.169)]$. Ancak amiloidoz grubunda ACTH stimulasyon testi sonrası 60. dk. kortizol yanitı daha düşüktü [624 (497-685) vs 743 (674-781) nmol/L, $p=0.011)$ ]. 20 hastanın 8'inde (40\%) bu değer $<500 \mathrm{nmol} / \mathrm{L}$ olarak bulundu. Ancak sadece bu sekiz hastanın üçünde (15\%) SKI <12 $\mathrm{nmol} / \mathrm{mg}$ olarak bulundu. Bu üç hasta klinik olarak da adrenal yetmezlikle uyumlu olabilecek bulgular taşlyordu.

Sonuç: Ağır proteinürisi olan renal tutulumlu amiloidoz hastalarında, adrenal yetmezlik araştırıIırken sadece ACTH stimulasyon testinin kullanılması yanlış pozitifliklere sebep olabilir. Bu grup hastaları SKI gibi hesaplanmış ölçümlerle birlikte değerlendirmek daha uygun olacaktır.

Anahtar kelimeler: Adrenal yetmezlik, albumin, KBG, kortizol, renal amiloidoz
Received: 17 February 2021

Accepted: 17 March 2021

Online First: 26 March 2021

Corresponding Author: D. Turgut

ORCID: 0000-0001-7474-5927

Baskent University Ankara Hospital, Department of Internal Medicine,

Division of Nephrology, Ankara, Turkey

didemturgut@yahoo.com

ORCID: 0000-0002-5494-8468

Iskenderun State Hospital,

Division of Nephrology,

Hatay, Turkey

H. Keskin

ORCID: 0000-0003-1794-4473

Istanbul Medeniyet University

Goztepe Training and

Research Hospital,

Department of Internal Medicine, Istanbul, Turkey

K. Agbaht ORCID: 0000-0003-3122-5491

Defne Hospital, Division of Endocrinology and Metabolism, Hatay, Turkey

E. Coskun Yenigun ORCID: 0000-0002-5963-605X F. Dede

ORCID: 0000-0002-5737-9854 University of Health Sciences, Ankara Bilkent City Hospital, Division of Nephrology, Ankara, Turkey 


\section{INTRODUCTION}

Amyloid A (AA) amyloidosis is a result of the deposition of serum amyloid A (SAA) protein fragments and related to a chronic inflammatory disease of either infectious or noninfectious etiology ${ }^{1}$. Renal involvement is frequent ${ }^{2}$, but endocrine system involvement has been extensively demonstrated at autopsies ${ }^{3}$. Detecting adrenal system problems in AA amyloidosis together with heavy proteinuria is a problem because interpretation of adrenal function tests is complicated. Urinary losses of albumin and hormone-binding proteins such as corticosteroid-binding globulin (CBG) results in an increased percentage of the unbound cortisol. Serum cortisol levels, if measured, would be at a healthy level in case of adrenal insufficiency ${ }^{4}$.

Reliable assessments of adrenal function in this patient group require realization of stimulation tests to prevent misdiagnosis of any adrenal problem before they become apparent. Adrenal insufficiency findings might be overlooked because autonomic involvement causes similar symptoms. A short adrenocorticotropin (ACTH) test $(250 \mu \mathrm{g})$ is the gold standard diagnostic tool for establishing adrenal insufficiency in the general population $^{5}$. Beyond stimulation tests, other metrics can estimate subtle adrenal insufficiency: Corrected measured hormone levels in proportion to CBG and albumin-calculated free cortisol $(\mathrm{CFC})$ as well as mathematical models (e.g., free cortisol index $(\mathrm{FCl})$, which is the ratio between total serum cortisol and $\mathrm{CBG}^{6}$, and $\triangle$ Cortisol). In this study, we investigated adrenocortical reserve in AA amyloidosis patients who also had impaired renal function or heavy proteinuria using the ACTH stimulation test, $\mathrm{cFC}$, and $\mathrm{FCl}$ after ACTH stimulation test.

\section{MATERIAL and METHODS}

\section{Study Population:}

Twenty patients with renal AA amyloidosis who were being followed at Ankara Education and Research Hospital and 25 healthy subjects as the control group were included in the study. The patient group had amyloidosis secondary to Familial Mediterranean Fever. The healthy control group had no known kidney or health problem. The diagnosis of AA amyloidosis was based on a kidney biopsy that was performed to docu- ment the etiology of proteinuria or impaired renal function. Exclusion criteria consisted of the following parameters: (1) previously documented adrenal insufficiency; (2) hypopituitarism; (3) pregnancy; (4) Cushing's syndrome; (5) malignancy; (6) type 2 diabetes mellitus; (7) use of corticosteroid medication within the previous year of the study; (8) ACTH allergy; and (9) age $<18$, or $>75$ years old.

Informed consents were obtained from all individual participants included in the study. All procedures involving human participants were in compliance with the ethical standards of the Institutional Ethics Committee of Ankara Education and Research Hospital and with the 1964 Helsinki Declaration and its later amendments or comparable ethical standards (Committee decision no: 2011-126; 09.07. 2011).

\section{Measurement of adrenocortical reserve:}

All study subjects were analyzed for their serum creatinine, serum albumin, and 24-h urinary protein levels with an automated clinical chemistry analyzer. After eight hours of overnight fasting, a short ACTH test $(250 \mu \mathrm{g})$ was administered intravenously (i.v.) to all patients and subjects of the healthy control group. Before ACTH injections, blood samples for basal serum cortisol and CBG were drawn at 8:00 AM. After ACTH injection, the $30^{\text {th }}$ and $60^{\text {th }}$ min blood samples for measurement of serum cortisol levels were drawn. Serum total cortisol was measured using an enzyme-linked immunosorbent assay (ELISA) technique (DRG, Cortisol ELISA). Serum CBG was measured by ELISA (Biovendor, human corticosteroid binding globulin ELISA).

A rational response to the $(250 \mu \mathrm{g}$ iv bolus) $\mathrm{ACTH}$ stimulation test is accepted as a rise in serum cortisol concentration after $60 \mathrm{~min}$ to a peak of $\geq 500 \mathrm{nmol} / \mathrm{l}$ $(\geq 20 \mathrm{ug} / \mathrm{dl})^{5}$. The change in cortisol increment $(\Delta$ Cortisol) was calculated as the difference between the $0^{\text {th }}$ minute and $60^{\text {th }}$ min serum cortisol levels. Relative adrenal insufficiency was defined as an increase of $<250 \mathrm{nmol} / \mathrm{l}$ in cortisol levels in the case of the highest cortisol level which was below $500 \mathrm{nmol} / \mathrm{I}^{7}$.

Free cortisol levels were calculated from Coolen's equation (recently discovered mathematical models): $\mathrm{U}=\sqrt{ }\left(\mathrm{Z}^{2}+0.0122 \mathrm{~T}\right)-\mathrm{Z}$ [U: plasma free cortisol $(\mu \mathrm{mol} / \mathrm{L})$ (after the statistical analysis it is converted and expressed as nmol/L), Z: $0.0167+0.182(\mathrm{G}-\mathrm{T})$, G: 
CBG $(\mu \mathrm{mol} / \mathrm{L}), \mathrm{T}$ : total cortisol $(\mu \mathrm{mol} / \mathrm{L})^{8} . \mathrm{CFC}<20$ $\mathrm{nmol} / \mathrm{L}$ was considered adrenal insufficiency.

Corrected total cortisol was calculated with the equation of $[(40-C B G) \times 0.7]+[(40-a l b u m i n) \times 0.2]+$ measured cortisol ${ }^{9}$. The free cortisol index $(\mathrm{FCI})$ was calculated by serum total cortisol/CBG (nmol/milligrams). A FCI response (after the ACTH test) of $\geq 12$ is accepted as a normal (healthy) adrenal response?

\section{Statistical Analyses:}

Data were expressed as means with standard deviation, frequencies (percentages), or medians with interquartile ranges (IQRs) as appropriate. The Shapiro-Wilk test was used to test the normality of the variables. Comparisons between AA amyloidosis patients and control subjects were performed with $\mathrm{X}^{2}$ (for categorical variables), independent samples $t$ test, or the Mann-Whitney $\mathrm{U}$ test (for continuous variables as appropriate). Correlation analysis was performed with Spearman's correlation coefficient.

All statistical tests were set at significance level of $p<0.05$. In the power analysis, we computed the required $\alpha$ value as 0.05 , hence our sample size in the patient group consisted of 20 patients. The difference between two independent groups, with a power $1-\beta=0.80$ and 0.75 effect size, sample size in the control group consisted of 25 subjects. All statistical analyses were done with SPSS 22.0 software (SPSS Inc, Chicago, IL) for Windows.

\section{RESULTS}

\section{Baseline Characteristics}

Twenty patients with AA amyloidosis and 25 healthy control subjects were included in the study. Seventeen $(85 \%)$ patients had nephrotic range proteinuria, and eight $(40 \%)$ patients had glomerular filtration rate (GFR) of $45-60 \mathrm{ml} / \mathrm{min} / 1.73 \mathrm{~m}^{2}$. The remaining subjects had GFR $>60 \mathrm{ml} / \mathrm{min} / 1.73 \mathrm{~m}^{2}$. Beyond exclusion criteria, none of the patients had any liver problem or any cardiac disease.

The clinical and laboratory characteristics of these patients are shown in Table 1 . No gender differences were observed between groups, and their serum fasting glucose, serum sodium $(\mathrm{Na})$, and serum potassium (K) levels were comparable. The AA amyloidosis group patients had higher serum creatinine levels and heavy proteinuria; and lower serum albumin, CBG, and GFR as expected.

Table 1. Comparison of baseline characteristics of patients and control groups.

\begin{tabular}{|c|c|c|c|}
\hline & $\begin{array}{l}\text { Amyloidosis } \\
\text { patients } \\
(\mathbf{n}=\mathbf{2 0})\end{array}$ & $\begin{array}{l}\text { Control } \\
(n=25)\end{array}$ & p-value \\
\hline Age & $43.4 \pm 16.5$ & $34.5 \pm 11.5$ & 0.089 \\
\hline Male n, \% & $11(55 \%)$ & $12(48 \%)$ & 0.641 \\
\hline \multicolumn{4}{|c|}{ Laboratory } \\
\hline Fasting glucose (mg/dL) & $80 \pm 11$ & $88 \pm 7.9$ & 0.902 \\
\hline Serum creatinine (mg/dL) & $1.43 \pm 0.66$ & $0.79 \pm 0.14$ & 0.002 \\
\hline $\operatorname{GFR}\left(\mathrm{ml} / \mathrm{min} / 1.73 \mathrm{~m}^{2}\right)$ & $55(32.7)$ & $99(17)$ & 0.001 \\
\hline Serum albumin (mg/dL) & $28.5(22.5)$ & $41(3.5)$ & $<0.001$ \\
\hline $\mathrm{CBG}(\mathrm{mg} / \mathrm{L})$ & $15.6(19.3)$ & $40.0(2.6)$ & $<0.001$ \\
\hline $\begin{array}{l}\text { 24-h urinary protein } \\
\text { (mg/day) }\end{array}$ & $5175(6480)$ & $100(33.5)$ & $<0.001$ \\
\hline Serum Na (meq/L) & $139.3 \pm 1.9$ & $138.6 \pm 2.0$ & 0.605 \\
\hline Serum K $(\mathrm{mEq} / \mathrm{L})$ & $4.59 \pm 0.74$ & $4.52 \pm 0.41$ & 0.512 \\
\hline
\end{tabular}

CBG: Cortisol binding globulin, GFR: Glomerular filtration rate, Na: sodium, K: potassium

\section{Results of adrenocortical reserve assessment}

Baseline and stimulated adrenal gland cortisol results are shown in Table 2. Although baseline cortisol levels and $\triangle$ Cortisol after ACTH stimulation were similar between the groups, stimulated serum cortisol $\left(60^{\text {th }}\right.$ min) levels were significantly lower in the patient group when compared to the control group $(p=0.011)$.

Table 2. Comparison of baseline adrenal tests and serum cortisol response to ACTH stimulation test.

\begin{tabular}{|c|c|c|c|}
\hline & $\begin{array}{l}\text { Amyloidosis } \\
\text { patients } \\
(\mathbf{n}=\mathbf{2 0})\end{array}$ & $\begin{array}{l}\text { Control } \\
(n=25)\end{array}$ & $\begin{array}{l}\mathbf{p} \\
\text { value }\end{array}$ \\
\hline $\begin{array}{l}\text { Cortisol } 0^{\text {th }} \text { min } \\
(\mathrm{nmol} / \mathrm{L})\end{array}$ & $258(297.2)$ & $350(120.8)$ & 0.169 \\
\hline $\begin{array}{l}\text { Cortisol } 60^{\text {th }} \text { min } \\
(\mathrm{nmol} / \mathrm{L})\end{array}$ & $624(187.3)$ & 743 (157.9) & 0.011 \\
\hline$\Delta$ Cortisol $(\mathrm{nmol} / \mathrm{L})$ & $282(205.8)$ & $392(121.5)$ & 0.169 \\
\hline $\begin{array}{l}\text { cFC, baseline } \\
(\mathrm{nmol} / \mathrm{L})\end{array}$ & $31.0(16.3-69.5)$ & $23.3(21.6-27.3)$ & 0.475 \\
\hline $\mathrm{FCI}$ & $8.0(3.4-10.9)$ & $17.7(14.2-16.4)$ & 0.008 \\
\hline $\begin{array}{l}\text { Cortisol response } \\
<500 \mathrm{nmol} / \mathrm{l}(\%)\end{array}$ & $8(40 \%)$ & $0(0)$ & \\
\hline $\begin{array}{l}\text { FCI response, } \\
\text { corrected }<12 \\
(\mathrm{nmol} / \mathrm{mg})\end{array}$ & $3(15 \%)$ & $0(0)$ & \\
\hline
\end{tabular}

cFC: Calculated free cortisol, FCl: Free cortisol index, $\triangle$ Cortisol: Cortisol increments after ACTH stimulation 
Table 3. Comparison of baseline adrenal tests and serum cortisol response to ACTH stimulation test.

\begin{tabular}{|c|c|c|}
\hline & $\begin{array}{l}\text { Amyloidosis } \\
\text { patients } \\
(\mathbf{n}=\mathbf{2 0})\end{array}$ & $\begin{array}{l}\text { Control } \\
(n=25)\end{array}$ \\
\hline Cortisol response $<500 \mathrm{nmol} / \mathrm{l}(\mathrm{n})$ & $8(40 \%)$ & 0 \\
\hline$\Delta$ Cortisol $<250 \mathrm{nmol} / \mathrm{L}(\mathrm{n})$ & $7(35 \%)$ & $4(16 \%)$ \\
\hline cFC, baseline, $<20 \mathrm{nmol} / \mathrm{L}$ (n) & $3(15 \%)$ & 0 \\
\hline $\begin{array}{l}\text { FCI response, corrected }<12 \\
\mathrm{nmol} / \mathrm{mg}(\mathrm{n})\end{array}$ & $3(15 \%)$ & 0 \\
\hline
\end{tabular}

cFC: Calculated free cortisol, FCI: Free cortisol index, $\triangle$ Cortisol: Cortisol increments after ACTH stimulation.
Eight of 45 participants in the study group had $60^{\text {th }}$ min cortisol response $<500 \mathrm{nmol} / \mathrm{l}$. All eight subjects were in the amyloidosis group. Any suspected adrenal insufficiency in patients according to different criteria is summarized in Table 3 . These eight patients have adrenal insufficiency at first glance and were evaluated in more detail. Three of those $8 \mathrm{AA}$ patients had $\mathrm{FCI}$ levels $<12 \mathrm{nmol} / \mathrm{mg}$. Similarly, cFC (estimated using wCoolen's equation) was lower than $20 \mathrm{nmol} / \mathrm{l}$ in these three patients. All control group subjects had both $\mathrm{FCl}>12 \mathrm{nmol} / \mathrm{mg}$ and $\mathrm{cFC}>20 \mathrm{nmol} / \mathrm{l}$. The $\Delta$ Cortisol levels were $<250 \mathrm{nmol} / \mathrm{l}$ in four subjects of

Table 4. Amyloidosis patients' characteristics who had cortisol response $<500 \mathrm{nmol} / \mathrm{l}$ to ACTH stimulation test.

\begin{tabular}{|c|c|c|c|c|c|}
\hline & Cortisol $0^{\text {th }} \min (\mathrm{nmol} / \mathrm{L})$ & Cortisol $60^{\text {th }}$ min $(\mathrm{nmol} / \mathrm{L})$ & $\Delta$ Cortisol $(\mathrm{nmol} / \mathrm{L})$ & cFC (nmol/L) & FCI (nmol/mg) \\
\hline Case 1 & 226.49 & 497.2 & 270.71 & 24 & 22 \\
\hline Case $2^{*}$ & 88.82 & 242 & 153.8 & 16.3 & 11.6 \\
\hline Case 3 & 176.03 & 484 & 307.97 & 31.6 & 21.3 \\
\hline Case 4 & 451.4 & 499.8 & 48.4 & 29.3 & 32.7 \\
\hline Case $5^{*}$ & 104.31 & 270.3 & 165.99 & 16.5 & 10.6 \\
\hline Case 6 & 305.42 & 495.50 & 190.08 & 28.6 & 26.7 \\
\hline Case $7^{*}$ & 84 & 342.16 & 258.16 & 14.7 & 10.9 \\
\hline Case 8 & 399 & 499 & 100 & 22 & 17.6 \\
\hline
\end{tabular}

cFC: Calculated free cortisol, FCI: Free cortisol index, $\triangle$ Cortisol: Cortisol increments after ACTH stimulation. * Patients with clinically compatible adrenal problems.

the control group. Finally, adrenal insufficiency was suggested in these three patients (15\%) with low stimulated cortisol $(<500 \mathrm{nmol} / \mathrm{L})$, low $\mathrm{FCl}(<12 \mathrm{nmol} /$ $\mathrm{mg}$ ), and low cFC levels. The results of eight patients are shown in Table 4 . When these three patients were questioned for signs of adrenal insufficiency, anorexia, nausea, vomiting, diarrhea, and hypotension were found and could be attributed to amyloidosis. They have been advised to go to the endocrinology and metabolism department for follow-up.

\section{DISCUSSION}

In our study, patients with amyloidosis had similar serum baseline cortisol but lower stimulated cortisol levels when compared to the control group. Stimulated total cortisol levels of $40 \%$ of AA patients were $<500$ $\mathrm{nmol} / \mathrm{L}$, which was interpreted as adrenal insufficiency for the general population. When considering the $\mathrm{FCI}$, three patients had $<12 \mathrm{nmol} / \mathrm{mg}$. All three patients had stimulated total cortisol levels of $<500 \mathrm{nmol} / \mathrm{L}$ suggesting adrenal insufficiency (15\%). The cFC also demonstrated similar results.
Evaluation of the adrenal gland requires measurement of the relevant hormones or their metabolites together with symptoms of adrenal insufficiency. However, it is not known to what extent the fibrils invaded the adrenal gland in amyloidosis and when it will cause clinically significant adrenal insufficiency. Widespread abnormalities of the autonomic nervous system might overlap with the same symptom patterns. In AA amyloidosis with heavy proteinuria, serum total cortisol measurements are likely to underestimate cortisol production because patients have lower CBG levels. In such patients, reduced serum cortisol concentrations may not correlate with decreases in free cortisol levels $^{10-12}$. Here, all patients with amyloidosis had an acceptedly lower median serum CBG level of 15.6 (9.3-28.4: normal: $40 \mathrm{mg} / \mathrm{l}) \mathrm{mg} / \mathrm{l}^{13}$. The available literature reports that the correlation between plasma levels of CBG and clinical symptoms is weak; low CBG levels are observed in asymptomatic patients. Conversely, elevated levels can occur in symptomatic patients ${ }^{14}$.

We also found that baseline serum cortisol and base- 
line calculated free cortisol levels were comparable in the patient and control groups. Brennan et al. ${ }^{10}$ and Davidson et al. ${ }^{15}$ reported cases of nephrotic syndrome due to amyloidosis with abnormal adrenal response to ACTH stimulation test. They attributed the subnormal response to the stimulation test as secondary to low CBG levels caused by urinary loss with heavy proteinuria ${ }^{11}$ as speculated in our study.

Borderline results after the ACTH stimulation test and abnormal CBG results must be reevaluated indirectly by using mathematically calculated cortisol measurements like $\mathrm{FCl}^{16}$. The strong correlation between serum free cortisol and $\mathrm{FCl}$ suggests that the $\mathrm{FCl}$ may be a useful surrogate marker for serum free cortisol ${ }^{6}$. As Dhillo et al. reported in their study, low cortisol levels appear to be related to low CBG levels in the settings of hypoalbuminemia. They applied $250 \mu \mathrm{g}$ short ACTH tests to 30 healthy individuals and analyzed cortisol and CBG levels at the $-30^{\text {th }}, 0^{\text {th }}$, and $+30^{\text {th }}$ min. Thirteen subjects who had $+30^{\text {th }}$ min cortisol $<550 \mathrm{nmol} / \mathrm{l}$ had significantly lower CBG levels. When they used $\mathrm{FCI}$ values, there was no significant differences in $\mathrm{FCl}$ values between subjects with $+30^{\text {th }}$ minute $>550 \mathrm{nmol} / \mathrm{l}$ and subjects with $<550 \mathrm{nmol} / \mathrm{I}^{9}$. In our study, amyloidosis patients had lower FCI levels $(p=0.008)$. Three of eight AA patients with cortisol response $<500 \mathrm{nmol} / \mathrm{l}$ had $\mathrm{FCl}<12 \mathrm{nmol} / \mathrm{mg}$, which is considered as an abnormal adrenal response with unclear clinical symptoms ${ }^{17}$. The cortisol/CBG ratio should be used to evaluate adrenal secretory capacity in amyloidosis patients with massive proteinuria and hypoproteinemia in addition to serum cortisol and the ACTH stimulation tests.

In critical illnesses, the diagnostic criteria for adrenal insufficiency include assessment of random cortisol level ${ }^{18}$, cortisol increment ( $\Delta$ cortisol) after cosyntropin stimulation test ${ }^{19}$, and/or free cortisol or total cortisol levels stratified by serum albumin levels ${ }^{20,21}$. In studies of critically ill patients, $\Delta$ Cortisol values of $<9 \mathrm{mg} / \mathrm{dl}$ (248 nmol/l) were accepted as non-responders to ACTH and they were associated with vasopressor hypo-responsiveness, higher risk of death, and improved response to prolonged corticosteroid supplementation $^{22}$. In our study, there was no statistical difference between the patient and control groups as for $\Delta$ Cortisol, but patients had statistically lower $\Delta$ Cortisol compared to controls in abnormal adrenal response (eight patients). When we separately checked the $\Delta$ Cortisol levels of subjects, four of eight had $<250$ $\mathrm{nmol} / \mathrm{l}$. Lower $\Delta$ Cortisol levels in the control group were seen in four patients. But none of them demonstrated decreased $60^{\text {th }}$ minute response. Thus, we did not accept them as adrenal insufficiency. As limitations, our limited number of patients did not allow determination of a cut-off level for $\Delta$ Cortisol. We did not measure $\mathrm{CBG}$ binding capacity or ACTH levels that may be considered to estimate adrenal gland problems. Further studies with a larger population would be required to address the use of cortisol increment after stimulation tests in amyloidosis patients.

In conclusion, an optimal assessment of the adrenal gland is essential in the management of patients with amyloidosis and heavy proteinuria. Failure to recognize the differences between adrenal insufficiency and disease-related symptoms can have potentially lifethreatening effects in these patients. Beyond this, unnecessary steroid replacement therapy may cause significant morbidity in terms of glucocorticoid side effects. ACTH stimulation tests and calculated $\mathrm{FCI}$ would guide clinicians not to skip adrenal insufficiency in amyloidosis patients with complex underlying problems.

\section{REFERENCES}

1. Pinney JH, Lachmann HJ. Systemic AA amyloidosis. Subcell Biochem. 2012;65:541-64. [CrossRef]

2. Ogawa S, Murakami T, Inoshima Y, Ishiguro N. Effect of heating on the stability of amyloid $A(A A)$ fibrils and the intra- and cross-species transmission of AA amyloidosis. Amyloid. 2015;22:236-43. [CrossRef]

3. Emeksiz H, Bakkaloglu S, Camurdan O, et al. Acute adrenal crisis mimicking familial Mediterranean fever attack in a renal transplant FMF patient with amyloid goiter. Rheumatol Int. 2010;30:1647-9. [CrossRef]

4. Chanson P, Guignat L, Goichot B, et al. Consensus Group 2: Adrenal insufficiency: screening methods and confirmation of diagnosis. Annales d'Endocrinologie. 2017;78:495-511. [CrossRef]

5. Bornstein SR, Allolio B, Arlt W, et al. Diagnosis and treatment of primary adrenal insufficiency: an endocrine society clinical practice guideline. J Clin Endocrinol Metab. 2016;101:364-89. [CrossRef]

6. le Roux CW, Sivakumaran S, Alaghband-Zadeh J, Dhillo W, Kong WM, Weheeler MJ. Free cortisol index as surrogate marker for serum free cortisol. Ann Clin Biochem. 2002;39:406-8. [CrossRef]

7. Bourne RS, Webber SJ, Hutchinson SP. Adrenal axis testing and corticosteroid replacement therapy in septic shock patients--local and national perspectives. Anaesthesia. 2013;58:591-6. [CrossRef] 
8. Coolens JL, Van Baelen H, Heyns W. Clinical use of unbound plasma cortisol as calculated from total cortisol and corticosteroid-binding globulin. J. Steroid Biochem. 1987;26:197-202. [CrossRef]

9. Dhillo WS, Kong WM, Le Roux CW, et al. Cortisol binding globulin is important in the interpretation of dynamic tests of the hypothalamic-pituitary-adrenal axis. Eur J Endocrinol. 2002;146:231-5. [CrossRef]

10. Brennan A, O'Connor KA, Plant WD, O'Halloran DJ. Nephrotic syndrome: cause of an abnormal response to the rapid ACTH stimulation test. Nephrol Dial Transplant. 2004;19:477-8. [CrossRef]

11. Tait JF, Burstein S. In vivo studies of steroid dynamics in man. In: Pincus V, Thimann KV, Astwood EB, editors. The Hormones (5). New York: Academic Press; 1964. p. 441 557. [CrossRef]

12. Brien TG. Human corticosteroid binding globulin. Clin Endocrinol (Oxf). 1981;14:193-212. [CrossRef]

13. Emptoz-Bonneton A, Cousin P, Seguchi K, et al. Novel human corticosteroid-binding globulin variant with low cortisol-binding affinity. J Clin Endocrinol Metab. 2000;85:361-7. [CrossRef]

14. Gagliardi L, Ho JT, Torpy DJ. Corticosteroid-binding globulin: the clinical significance of altered levels and heritable mutations. Mol Cell Endocrinol. 2010;316:2434. [CrossRef]

15. Davidson JS, Bolland MJ, Croxson MS, Chiu W, Lewis JG. A case of low cortisol-binding globulin: Use of plasma free cortisol in interpretation of hypothalamic-pituitaryadrenal axis tests. Ann Clin Biochem. 2006;43:237-9. [CrossRef]

16. le Roux CW, Chapman GA, Kong WM, Dhillo WS, Jones J, Alaghband-Zadeh J. Free cortisol index is better than serum total cortisolin determining hypothalamic-pituitary-adrenal status in patients undergoing surgery. J Clin Endocrinol Metab. 2003;88:2045-8. [CrossRef]

17. Danby P, Harris KP, Williams B, Feehally J, Walls J. Adrenal dysfunction in patients with renal amyloid. Q J Med. 1990;76:915-22. PMID: 2236477.

18. Marik PE, Zaloga GP. Adrenal insufficiency during septic shock. Crit Care Med. 2003;31:141-5. [CrossRef]

19. Cooper MS, Stewart PM. Corticosteroid insufficiency in acutely ill patients. N Engl J Med. 2003;348:727-34. [CrossRef]

20. Arafah BM. Hypothalamic-pituitary adrenal function during critical illness: Limitations of current assessment methods. J Clin Endocrinol Metab. 2006;91:3725-45. [CrossRef]

21. Ho JT, Al-Musalhi H, Chapman MJ, et al. Septic shock and sepsis: A comparison of total and free plasma cortisol levels. J Clin Endocrinol Metab. 2016;91:105-14. [CrossRef]

22. Annane D, Maxime V, Ibrahim F, Alvarez JC, Abe E, Boudou P. Diagnosis of adrenal insufficiency in severe sepsis and septic shock. Am J Respir Crit Care Med. 2006;174:1319-26. [CrossRef] 